Volume 3 No. 1, Juni 2018

P ISSN 2442-594X | E ISSN 2579-5708

http://journal.iainlangsa.ac.id/index.php/tibyan

DOI: $10.32505 /$ tibyan.v3i1.487

\title{
MEMAHAMI BAHASA ALQURAN BERBASIS GRAMATIKAL (Kajian tehadap Kontribusi Pragmatik dalam Kajian Tafsir)
}

\section{Understanding of The Gramatic Based Alquran Language (Study of Pragmatic's Contributions in Interpretation Studies)}

\author{
Fathurrosyid \\ INSTIKA Guluk-Guluk Sumenep \\ fathurrosyid090381@gmail.com
}

\begin{abstract}
Abstrack
Interacting with the verses of the Qur'an by conducting analytical activities that stop at the linguistic context and its grammatical structure will not be sufficient to pursue the ultimate truth (maqasid asasiyah). Under such conditions, a secondary device is required to open layers of messages that are settled in text that can not be comprehensively understood from the grammatical perspectives of the text. With the primary data source is the Qur'an about the story of Maryam and linguistic analysis can be conclused: First, the pragmatics of the Qur'an is a discipline that examines the Qur'ân from the standpoint of the relationship between the dyberic linguistic context; and triadic non-linguistic contexts. Secondly, the basic assumption of pragmatics of the Qur'an is because this scripture does not descend in empty space, but has a dialectical connection to Arab socio-cultural reality. Thirdly, the contribution of prasetics in the study of Qur'anic interpretation shows that, (a) the presence of the theory of perlokusi as the instrument of determining the meaning of speakers whether in the form of declarative, imperative or other sentences. (b) implicatures as a deadlock solution of textual grammatical understanding and (c) the presence of pragmatics itself as a tool of understanding based on its context oriented to appropriateness in meaning and oriented appropriateness in form.
\end{abstract}

Keywords; Grammatical, Contributions and Pragmatics

\begin{abstract}
Abstrak
Berinteraksi dengan ayat-ayat Alquran dalam melakukan kegiatan analitis tidak hanya berhenti pada konteks linguistik dan struktur tata bahasanya tetapi juga mengejar kebenaran tertinggi (maqasid asasiyah). Dalam kondisi seperti itu, perangkat sekunder diperlukan untuk membuka lapisan pesan yang terdapat dalam teks yang tidak dapat dipahami secara komprehensif dari perspektif gramatikal dari teks. Dengan sumber data primer Alquran tentang kisah Maryam dan analisis linguistik, studi ini menghasilkan
\end{abstract}


kesimpulan sebagai berikut: Pertama, pragmatik Al-Qur'an adalah disiplin yang menguji Al-Qur'an dari sudut pandang hubungan antara konteks linguistik yang suram; dan konteks non-linguistik triadic. Kedua, asumsi dasar pragmatik Al-Qur'an adalah karena kitab suci ini tidak diturunkan dalam ruang kosong, tetapi memiliki hubungan dialektik dengan realitas sosio-budaya Arab. Ketiga, kontribusi prasetika dalam kajian tafsir AlQur'an menunjukkan bahwa, (a) keberadaan teori perlokusi sebagai alat penentu makna penutur apakah dalam bentuk deklaratif, imperatif atau kalimat lain. (b) implikatur sebagai solusi kebuntuan pemahaman gramatikal tekstual dan (c) kehadiran pragmatik itu sendiri sebagai alat pemahaman berdasarkan konteksnya yang berorientasi pada kepatutan dalam arti dan kepantasan yang berorientasi dalam bentuk

Keywords; Gramatikal, Kontribusi, Prakmatik.

\section{Pendahuluan}

Kitab suci Alquran merupakan firman Allah swt.yang berisi pesan-pesan moral yang ditujukan buat kehidupan manusia di sepanjang tempat dan waktu. Pesan-pesan tersebut disampaikan menggunakan nalar dan piranti kultural-geografis Arab berupa Bahasa Arab (qur'anan 'arabiyyan). ${ }^{1}$ Jatuhnya pilihan Bahasa Arab tersebut agar bisa dimengerti ${ }^{2}$ oleh komunitas yang hendak dituju Alquran, yaitu masyarakat Mekkah dan Madinah. ${ }^{3}$

Fenomena di atas secara eksplisit memberikan suatu pesan moral bahwa Alquran tidak turun dalam ruang kosong (cultural vacum), akan tetapi mempunyai hubungan dialektis dengan realitas sosial yang berkembang pada saat itu; yaitu berinteraksi, berdialektika dan bernegosiasi dengan kondisi sosial masyarakat Arab. ${ }^{4}$ Artinya, kondisi sosial, geografis dan psikologi masyarakat Arab ketika itu merupakan salahsatu pertimbangan menarik yang diangkat ke permukaan.

Dialektika Alquran dengan realitas sosiologis-imajinasi Arab tersebut merupakan fakta sejarah bahwa Alquran merupakan kitab suci yang menggunakan media komunikasi berupa bahasa yang merupakan sistem simbol bunyi dan bisa berfungsi apabila terdapat pemahaman antara penutur dan mitra tutur. ${ }^{5}$ Namun demikian, bahasa

\footnotetext{
${ }^{1}$ Terdapat sekian banyak ayat Alquran yang menjelaskan bahwa media komunikasi yang digunakan Alquran adalah nalar Arab, setidaknya terdapat dalam sembilan surat, yaitu QS: 12: 2, 13:37, 16:103, 26:195, 39:28, 41:3, 42:7, 43:3 dan 46:12. Lihat selengkapnya; Muhammad Fu'ad 'Abd al-Baqi, alMu'jam al-Mufahras li Alfaz Alquran (Kairo: Dar al-Kutb al-Misriyah, 1364), 456. Lihat juga; al-Husni al-Maqdisi, Fath al-Rahman li Talib Ayat Alquran (Jakarta: Diponegoro, t.th), h. 295.

${ }^{2}$ Jalal al-Din al-Suyuti, al-Itqan fi' Ulum Alquran, Vol. I (Beirut: Dar al-Fikr, 1414), h. 87.

${ }^{3}$ Muhammad al-Tahir Ibn 'Ashur, Tafsir al-Tahrir wa al-Tanwir, Vol. XV (Beirut: Mu'asasah alTarikh al-‘Arabi, 2000), h. 106.

${ }^{4}$ M. Faruq al-Nabhan, al-Madkhal li al-Tashri‘ al-Islami, (Beirut: Dar al-Qalam, 1981), 83. Lihat juga; Ali Sodiqin, Antropologi Al Qur'an (Yogyakarta: Arruz Media Group, 2008), h. 12.

${ }^{5}$ Mahmud Fahmi Hijazi, 'Ilm al-Lughah al-'Arabiyah (Kairo: Dar Garib, t.th.), h. 10.
} 
Alquran mempunyai karakter dan genre yang jauh lebih spektakuler dari bahasa lainnya, ${ }^{6}$ utamanya pada dimensi sastranya.

Persoalan yang muncul kemudian, bagaimana upaya memahami dimensi sastra dan pesan moral yang diusung oleh Alquran?.Tentu saja, sebagai kitab petunjuk, Alquran sejatinya ditelusuri dan dikaji dengan pendekatan bahasa untuk dapat menguak misteri pesan berharga yang terselubung di dalamnya, dengan tetap membiarkan Alquran berbicara dengan sendirinya, tanpa harus diseret kedalam perspektif hiddenideology, semisal teologis, sufistik, politik dan lainnya yang selalu atomistik dan parsialistik (qira'ah talwiniyyah). ${ }^{7}$ Mengkaji dan memahami Alquran dengan cara membiarkan dirinya berbicara, secara otomatis telah mengembalikan Alquran pada watak dan karakter aslinya sebagai "teks" bahasa, sebab menurut kaca mata Amin al-Khuli, Alquran sebagai kitab “al-'arabiyyah al-akbar", tentu proses interpretasi melalui dimensi bahasa dan sastra merupakan prioritas pertama dan utama. $^{8}$

Upaya interpretasi terhadap Alquran dengan menggunakan kajian bahasa dan sastra selama ini dalam ilmu-ilmu studi Alquran disebut interpretasi linguistik yang dalam Bahasa Arab populer dengan sebutan nama al-Tafsir al-Lughawi. ${ }^{9}$ Hanya saja analisis yang berhenti hanya pada konteks linguistik dan struktur gramatikalnya tidak akan cukup memadai untuk mengejar kebenaran hakiki (maqasid asasiyyah) yang diusung oleh teks. Analisis pemahaman terhadap suatu teks semestinya dilanjutkan pada penyingkapan makna yang terdiamkan (al-maskut 'anhu), yaitu makna yang tidak tercakup secara verbatim di dalam aksara sebuah teks. Pencapaian terhadap maknamakna itu akan meniscayakan adanya sebuah analisa yang bukan hanya terhadap

\footnotetext{
${ }^{6}$ Nasr Hamid Abu Zaid, Mafhum al-Nass; Dirasat fi ${ }^{\circ}$ Ulum Alquran (Beirut: Markaz al-Thaqafi al'Arabi, 1990),60. Bandingkan dengan; al-Suyuti, al-Itqan fi 'Ulum Alquran, Vol. I, h. 141. Muhyiddin al-Darwaish, I'rab Alquran wa Bayanuh, Vol. IV (Shiriai: Dar al-Irshad, t.th.), h. 217. Lihat juga; Fathurrosyid. "Eksistensi Alquran: Kajian Ontologi, Epistemologi dan Aksiologi" dalam Studi Alquran (Surabaya: Kopertais IV Press, 2015), h. 15.

${ }^{7}$ Dalam konteks ini, literatur menarik yang membahas tentang corak dan ideologi penafsiran, bisa dilihat misalnya, Muhammad Husin al-Dhahabi, al-Tafsir wa al-Mufassirun (t.tp.: tp., 1396). 'Abd alQadir Muhammad Salih, al-Tafsir wa al-Mufassirun fi al-'Asri al-Hadith, (Beirut: Dar al-Ma'rifah, 1424). Ignaz Gold Ziher, Madhahib al-Tafsir al-Islami (Beirut: Dar Iqra', 1403). Fahd 'Abdurrahman bin Sulaiman al-Rumi, Manhaj al-Madrasah al-'Aqliyah al-Hadithah fi al-Tafsir (Riyad: al-Buhuth al'Ilmiiyah wa al-Ifta', 1403). Fahd 'Abdurrahman bin Sulaiman al-Rumi, Ittijahat al-Tafsir fi al-Qarn al'Ashr (Riyad: Mu'asasah Risalah, 1418). Musa Ibrahim al-Ibrahim, Buhuth Manhajiyah fi 'Ulum Alquran al-Karim (Amman: Dar 'Ammar, 1996), h. 91-120.

${ }^{8}$ Amin al-Khuli, Manhaj Tajdid fi al-Nahw wa al-Balaghah wa Tafsir wa al-Adab (Kairo: Dar alMa'rifah, 1961), h. 230-233.

${ }^{9}$ Jenis tafsir ini telah banyak diaplikasikan oleh para mufasir, baik era klasik (formatif), pertengahan (ideologis), modern dan kontemporer (reformatif), bahkan pernah dipraktikkan sendiri oleh Rasulullah sebagai sosok yang paling otoritatif dalam menafsirkan Alquran. Lihat selengkapnya; Musa'id Nasir alTayyar, al-Tafsir al-Lughawi li Alquran al-Karim,(t.tp.: Dar Ibn al-Jawzi, t.th.), 183-448. Bandingkan dengan; al-Rumi, Ittijahat al-Tafsir fi al-Qarn al-'Ashr, 867. Lutfi al-Sabag, Lamhat fi 'Ulum Alquran wa Ittijahat al-Tafsir (Beirut: al-Maktab al-Islami, 1410), h. 219.
} 
struktur kalimat per-se, melainkan yang justeru fondasional adalah analisa kelas, struktur sosial dan budaya yang melingkupi sejarah kehadiran teks itu sendiri. ${ }^{10}$

Dalam kondisi yang demikian, perlu suatu perangkat sekunder untuk membuka lapisan-lapisan pesan yang terendap dalam teks yang tidak dapat secara tuntas dipahami dari perspektif semantika teksnya.Perangkat tersebut dalam kajian ilmu linguistik disebut pragmatik.Kehadiran pragmatik dalam kajian linguistik merupakan kajian yang memperlakukan makna bahasa sebagai relasi yang melibatkan tiga segi (triadic), yaitu hubungan tiga arah yang melibatkan bentuk, makna dan konteks. Selain itu, pragmatik juga kajian yang terikat konteks (context-dependent). ${ }^{11}$ Konteks yang dimaksudkan dalam pragmatik ini bukan hanya konteks personal yang juz'i partikular (asbab al-nuzul khassah), melainkan juga konteks impersonal yang kulli-universal (asbab al-nuzul 'ammah). ${ }^{12}$

Berangkat dari realitas tersebut, penelitian ini hendak mengungkap tiga persoalan penting; Pertama, apa yang dimaksud dengan pragmatik dan pragmatika Alquran?.Kedua, bagaimana asumsi dasar pragmatika Alquran dan langkahlangkanya?.Ketiga, apa saja kontribusi teori pragmatik dalam kajian tafsir Alquran?.Adapun tujuan ketiga pertanyaan tersebut, selain untuk memahami konsep pragmtika Alquran, asumsi dasar juga untuk mengungkap bentuk-bentuk kontribusi kajian pragmatik dalam kajian tafsir Alquran.

Penelitian ini merupakan penelitian kepustakaan (library research), yaitu kajian terhadap kontribusi teori pragmatik dalam kajian tafsir Alquran dengan menggunakan data kisah Maryam yang terdapat dalam Alquran. Sedangkan sifat datanya berupa data deskriptif berupa kata-kata tertulis. ${ }^{13}$ Sumber data primer penelitian ini berupa Alquran, sementara data sekundernya berupa kitab-kitab tafsir atau buku-buku yang mempunyai relevansi dengan tema kisah-kisah dan teori pragmatik.

Setelah data terkumpul, prosedur selanjutnya dilakukan analisis data dengan langkah sebagai berikut; Pertama, analisis kebahasaan yang meliputi analisis wilayah semantik, sintaksis, morfologis dan sintagmatik-paradigmatik. ${ }^{14}$ Kedua, analisis wacana kritis yang digunakan untuk menyingkap kepentingan dan ideologi yang terselip dibalik bahasa yang digunakan.Bahasa dalam konteks ini, dipahami sebagai representasi yang berperan dalam membentuk subjek tertentu, tema-tema wacana

${ }^{10}$ Abd Muqsith Ghazali, Metodologi Studi Alquran (Jakarta: Gramedia Pustaka Agama, 2009), h. 119. Bandingkan dengan; 'Abd al-Sabur Shahin, 'Arabiyat Alquran (t.tp.: Maktabah al-Shahab, t.th.), h. 67.

${ }^{11}$ Lihat selengkapnya; Joko Nurkamto, Pragmatik (Surakarta: FKIP Universitas Sebelas Maret, 2002), h. 2.

${ }^{12}$ Konteks personal-partikular atau konteks mikro (asbab al-nuzul khassah) dalam ilmu Sabab alNuzul disebut dengan istilah nuzulan (turun karena sebab-sebab tertentu), sementara konteks impersonal-universal atau konteks makro (asbab al-nuzul 'ammah) disebut dengan istilah ibtida'an (turun tanpa didahului oleh sebab-sebab tertentu. Liha selengkapnya; al-Suyuti, al-Itqan fi 'Ulum Alquran, Vol. I (Beirut: Dar al-Fikr, 1979), h. 29.

${ }^{13}$ Lexy J. Moleong, Metodologi Penelitian Kualitatif, (Bandung: Remaja Rosdakarya,2009), h. 4.

${ }^{14}$ Abdul Mustaqim, Epistemologi Tafsir Kontemporer, (Yogyakarta: LKiS, 2012), h. 6-7. 
tertentu maupun strategi di dalamnya. ${ }^{15}$ Ketiga, analisis fenomenologis terhadap wacana yang dikisahkan untuk membongkar kontribusi teori pragmatik dalam kajian tafsir Alquran.

\section{Pragmatika Alquran; Basis Epistemologis}

Kalimat "pragmatika Alquran" merupakan kata majemuk yang berasal dari kata "pragmatik" dan "Alquran". Karena itu, penulis akan mengurai satu persatu terlebih dahulu kedua kata tersebut secara definitif. ${ }^{16}$ Kata "pragmatik" itu sendiri didefinisikan oleh tiga pakar bahasa sebagai berikut;

Pertama, pendapat George Yule, yang menyebutkan empat definisi, (1) kajian terhadap maksud pembicara (speaker meaning), (2) kajian terhadap makna sesuai konteksnya (contextual meaning), (3) kajian terhadap makna yang diujarkan atau dikomunikasikan oleh pembicara (how more gets communicated than is said), (4) kajian terhadap bentuk ekspresi sesuai jarak sosial yang membatasi partisipan yang terlibat dalam percakapan tertentu (the expression of relative distance). ${ }^{17}$

Kedua, JennyThomas membagi definisi pragmatik dengan dua bagian sesuai dengan kecenderungan masing-masing; (1) jika dilihat dari sudut pandang sosial, maka pragmatik berhubungan dengan makna pembicara (speaker meaning). (2) jika diamati dari perspektif kognitif, maka posisi prgamatik berhubungan dengan interpretasi ujaran (utterance interpretation). ${ }^{18}$ Karena itu, definisi pragmatik menurut Thomas adalah suatu disiplin keilmuan yang mengkaji makna dalam interaksi (meaning in action). Hal ini disebabkan pemaknaan merupakan proses dinamis yang melibatkan negosiasi antara pembicara dan pendengar serta antara konteks ujaran (fisik, sosial dan linguistik) dan makna potensial yang muncul dari sebuah ujaran. ${ }^{19}$

Ketiga, Stephent C. Levinson, juga mengemukakan definisi pragmatik dengan dua macam; (1) "pragmatics is the study of the relations between language and context the are basic to an account of the language understanding" (Pragmatik adalah studi hubungan antara bahasa dengan konteksnya yang merupakan dasar penentu pemahamannya). (2) "pragmatics is the study of the ability of language users to pair sentences with the contexs in wich they would be appropriate" (pragmatik adalah studi kemampuan para pengguna bahasa untuk menyesuaikan pasangan kalimat dengan konteks kebahasaan). ${ }^{20}$ Definisi pertama berorientasi pada "appropriateness in meaning" (ketepatan isi) yaitu apa yang harus dikatakan seorang penutur dalam situasi tertentu, seperti membicarakan pesta ulang tahun pada saat membesuk orang sakit.

\footnotetext{
${ }^{15}$ Eriyanto, Analisis Wacana; Pengantar Analisis Teks Media (Yogyakarta: LKiS, 2001), h. 7.

${ }^{16}$ Fathurrosyid, Pragmatika Alquran; Model Pemahaman Kisah Sayyidah Maryam yang Terikat Konteks, dalam Suhuf; Jurnal Kajian Alquran dan Budaya, Lajnah Pentashihan Mushaf Alquran, Balitbang dan Diklat Kemenag RI, Vol. 09, No. 02, h. 113.

${ }^{17}$ George Yule, Pragmatics, (Oxford: Oxford Universty Press, 2006), h. 3-4.

${ }^{18}$ Jenny Thomas, Meaning in Interaction; an Introduction to Pragmatics (New York: Longman, 1995), h. 2.

${ }^{19}$ Ibid., h. 22

${ }^{20}$ Stephent C. Levinson, Pragmatics (Cambridge: Cambridge Univercity Press, 1983), h. 31-34.
} 
Sementara pada definisi kedua mengarah pada persoalan "appropriateness in form" (ketepatan bentuk) yaitu bagaimana seorang penutur dapat mengatakan sesuatu secara tepat, seperti memanggil "bos" pada seorang ustadz atau dosen.

Dari ketiga definisi di atas dapat disimpulkan bahwa pragmatik adalah suatu disiplin keilmuan yang mengkaji relasi bahasa dengan pengguna bahasa (language users), maksud pembicara (speaker meaning) dan relasi antar bahasa dengan konteks kebahasaaan (language context) yang menjadi dasar penentu pemahaman. ${ }^{21}$ Dengan demikian, keberadaan konteks kebahasaan merupakan komponen yang signfikan dalam pemahaman mengingat suatu kata atau kalimat tidak akan lahir dalam ruang kosong (vacum cultural), tetapi berdialektika dengan realitas sosial yang mengitarinya. Karena itu, tugas mitra tutur dalam memahami bahasa tidak saja dituntut mengetahui makna kata berdasarkan relasi gramatikalnya saja, tetapi yang lebih objektif harus mampu menarik kesimpulan berdasarkan konteks kebahasaan.

Sementara definisi Alquranitu sendiri, sebagaimana yang ditawarkan oleh ahli fikih dan ushul fikih bahwa Alquranadalah firman Allah swt. yang berupa mukjizat, diturunkan kepada Nabi Muhammad saw, tertulis dalam mushaf yang disampaikan secara mutawatir dan bagi yang membacanya dinilai ibadah. Firman tersebut dimulai dari surat al-Fātihahah serta diakhiri dengan surat an-Nās. ${ }^{22}$

Berdasarkan dua definisi di atas, maka kesimpulan penulis bahwa pragmatika Alquran adalah suatu disiplin ilmu yang mengkaji Alqurandari sudut pandang relasi antara konteks linguistik (linguistic meaning) yang bersifat diadik dan konteks nonlinguistik (speaker meaning) yang bersifat triadik. Konteks kebahasaan yang dimaksudkan penulis dalam kajian tersebut adalah susunan gramatikal ayat-ayat yang terdapat dalam al-Qur'ān, sedangkan konteks non-kebahasaan yaitu kajian terhadap situasi dan kondisi tertentu, baik sosial, geografis dan psikologi budaya Arab yang menjadi latar turunnya al-Qur'ān.

\section{Ranah Kajian Pragmatika Alquran}

Menurut Nababan, objek kajian yang disepakati tokoh linguistik dalam studi pragmatik meliputi empat hal; Pertama, deiksis. Kedua, implikatur. Ketiga, praanggapan. Keempat, tindak tutur. ${ }^{23}$ Hanya saja, dari keempat objek tersebut, penulis fokuskan kepada kontribusi dibidang teori tindak tutur dan implikatur saja.

\footnotetext{
${ }^{21}$ Bambang Kaswati Purwo, Pragmatik dan PengajaranBahasa; Menyibak Kurikulum 1984 (Yogyakarta: Kanisius, 1990), 15. Lihat juga; Henry Guntur Tarigan, Pengajaran Pragmatik (Bandung: Angkasa, 1990), h. 33 Lihat juga; Asim Gunarwan, Pragmatik: Pandangan Mata Burung (Jakarta: Unika Atmajaya, 1993), h. 3.

${ }^{22}$ Akram Khalīfah, Jam'u al-Qur'ān; Dirasah Tahা̄liyyah li Marwiyyatih (Beirut: Dar al-Kutb, 1427), h. 19. Lihat juga, Nur ad-Dīn 'Itr, 'Ulum Alquranal-Karim (Damaskus: Matba' ah al-Sabah, 1414), h. 10. Bandingkan dengan; Fathurrosyid, "Eksistensi al-Qur'ān; Kajian Ontologi, Epistemologi dan Aksiologi”, Studi Alquran(Surabaya: Kopertais IV Press, 2015), h. 12.

${ }^{23}$ Bambang Kaswati Purwo,Deiksis dalam Bahasa Indonesia (Jakarta: PN Balai Pustaka, 1984), h. 10. Lihat juga; PWJ. Nababan, Ilmu Pragmatik; Teori dan Penerapannya (Jakarta: Departemen Pendidikan dan Kebudayaan, 1987), h. 18.
} 
Tindak tutur (speech act) secara terminologis adalah pengucapan suatu kalimat yang tidak semata-mata menanyakan jawaban tertentu, melainkan juga menindakkan sesuatu. ${ }^{24}$ Misalnya, ungkapan seorang ibu kost, "Sudah pukul 21.00, mas".Kalimat tersebut tidak hanya berfungsi sebagai kalimat informatif, tetapi juga bermakna imperatif; yaitu perintah agar pemuda tersebut hendaknya segara pulang meninggalkan tempat kost.

Persoalannya adalah bagaimana menentukan maksud dari aktivitas ujaran terebut. Pertanyaan ini dijawab oleh Austin, bahwa dalam teori tindak tutur terdapat tiga klasifikasi tindakan yang dapat dilakukan melalui tuturan, ${ }^{25}$ yaitu;

Pertama, Tindak Lokusi (locutionary acts), yaitu tindak mengucapkan sesuatu dengan kata, frasa dan kalimat sesuai dengan makna yang terkandung dalam kamus.Tindak tutur ini dapat disebut sebagai the act of saying something.Dengan demikian, pemahaman terhadap jenis tuturan ini hanya berbasis pada makna tekstual at au gramatikalnya saja.

Kedua, Tindak Illokusi (illocutionary acts), yaitu tindak tutur yang berfungsi melakukan suatu tindakan.Tindak tutur ini disebut sebagai the act of doing something.Pemahaman terhadap tuturan ini harus dinegosiasikan dengan konteks yang ada. Misalnya, tuturan, “Tanganku gatal!”, jika dipahami dalam konteks lokusi berarti menunjukkan kalimat informatif, bahwa tangannya gatal, sementara jika dipahami dalam konteks illokusi menunjukkan, bahwa penutur menginginkan mitra tuturnya agar mengambilkan obat penghilang rasa gatal.

Tindak tutur illokusi ini, diklasifikasikan oleh Searle ${ }^{26}$ ke dalam lima macam bentuk tuturan, sebagai berikut; (1) asertif (assertives), yakni tuturan yang mengikat penutur pada kebenaran proposisi yang diungkapkan, misalnya: menyatakan, menyarankan, membuang, mengeluh, mengadu dan mengklaim. (2) direktif (direktives), yakni tuturan yang dimaksudkan untuk membuat pengaruh agar sang mitra tutur melakukan tindakan tertentu, misalnya memesan, memerintah, memohon, menasihati, dan merekomendasi. (3) ekspresif (expressives), adalah tuturan yang berfungsi menyatakan atau menunjukkan sikap psikologis penutur terhadap suatu keadaan, misalnya berterima kasih, dan memberi selamat. (4) komisif (commissives), yakni tuturan yang berfungsi menyatakan janji atau penawaran, misalnya berjanji, bersumpah, dan menawarkan sesuatu. (5) deklarasi (declarations), yakni tuturan yang menghubungkan isi tuturan dengan kenyataannya, misalnya berpasrah, memecat, membaptis, memberi nama, mengangkat, mengucilkan, dan menghukum.

\footnotetext{
${ }^{24}$ George Yule, Pragmatic(New York: Oxford University Press, 1996), h. 47-48. Bandingkan denan; Rustono, Pokok-pokok Pragmatik(Semarang: IKIP Semarang Press, 1999), h. 33.

${ }^{25}$ Jenny Thomas, Meaning In Interaction; An Introduction To Pragmatics(London and New York: Routledge, 1995), h. 49. Bandingkan dengan; Jacob L. Mey, Pragmatics An Introduction(Hongkong: Blackwell Publishing, 2001),h. 120-122. Bandingkan dengan: Abdul Chaer, Sosiolinguistik; Perkenalan Awal, (Jakarta: Rineka Cipta, 2004),h. 56-60.

${ }^{26}$ Charles W. Kreidler, Introducing English Semantic, (London: Routledge, 1998), h. 183-192.
} 
Ketiga, Tindak Perlokusi (perlocutionary acts), yaitu tuturan yang memiliki efek yang ditimbulkan dari sebuah tuturan, baik disengaja atau tidak yang disebut dengan the act of effecting someone.Tuturan "Tanganku gatal!" bisa menimbulkan efek rasa takut pada mitra tutur, karena tuturan itu diucapkan oleh seorang tukang pukul.

Sedangkan yang dimaksud dengan implikatur adalah suatu proposisi yang diimplikasikan oleh suatu tuturan dalam suatu konteks dan proposisi tersebut bukanlah merupakan bagian dari tuturan itu sendiri. ${ }^{27}$ Artinya, posisi implikatur merupakan suatu kajian terhadap suatu ujaran yang menyiratkan sesuatu yang berbeda dengan ucapan yang sebenarnya. ${ }^{28}$ Sedangkan urgensi posisi implikatur dalam kajian pragmatik disebabkan empat hal; Pertama, dapat menjelaskan fakta-fakta bahasa secara fungsional.Kedua, dapat menjelaskan makna secara implisit dari bahasa eksplisit.Ketiga, dapat menyederhanakan deskripsi dari sisi struktur maupun substansi makna. Keempat, dapat memberikan penjelasan berbagai dasar fakta kebahasaan yang tidak relevan secara struktural tetapi mempunyai relevansi secara faktual. ${ }^{29}$

\section{Asumsi Dasar Pragmatika Alquran}

Kitab suci Alquran merupakan firman Allah swt. yang menggunakan piranti kultural Bahasa Arab $^{30}$ dalam rangka merespon suatu kasus yang terjadi di Arab. Penggunaan piranti tersebut untuk memudahkan masyarakat Arab sebagai komunitas pengguna Bahasa Arab, dalam melakukan interpretasi terhadap pesan-pesan moral Alquran. ${ }^{31}$ Dengan demikian, posisi Alquran merupakan media komunikasi dalam rangka merespon kasus yang terjadi dalam konteks lokal-insidental komunitas Mekkah dan Madinah.

Karena itu, sehubungan Alquran merupakan kitab suci yang menggunakan jaring lokalitas Arab, maka diperlukan perangkat sekunder untuk membongkar lapisanlapisan pesan yang terendap dalam teks itu sendiri yang tidak dapat secara tuntas dipahami dari perspektif semantika teksnya. Hal ini dilakukan dalam rangka untuk mencapai titik subtilitas intelligendi (ketepatan pemahaman) dan subtilitas explicandi (ketepatan penjelasan) terhadap al-Qur'ān. Perangkat sekunder tersebut dalam kajian ilmu linguistik disebut kajian pragmatik. Asumsi dasarnya adalah sebagai berikut:

Pertama, Alquran adalah kitab suci yang tidak turun dalam ruang kosong (vacum cultural), akan tetapi mempunyai hubungan dialektis dengan realitas sosial-budaya; yaitu berinteraksi, bernegosiasi dan berdialektika dengan kondisi sosial masyarakat

\footnotetext{
${ }^{27}$ Gerald Gazdar, Pragmatic Implicature, Presupposition and Logical Form, (New York: Academic Press, 1979), 38. Lihat juga; Jacob L. Mey, Pragmatics An Introduction,h. 45.

${ }^{28}$ Mulyana, KajianWacana, 11. Lihat juga; Bambang Kaswati Purwo, Deiksis dalam Bahasa Indonesia, 2.

${ }^{29}$ Stephen C. Levinson, Pragmatic(Cambridge: Cambridge University Press, 1992), h. 31.

${ }^{30}$ Fathurrosyid, Semiotika Kisah al-Qur'ān; Membedah Perjalanan Religi Raja Sulaiman dan Ratu Balqis (Surabaya: Pustaka Radja, 2015), h. 3.

${ }^{31}$ Muḥammad at-Țāhir Ibn 'Āshūr, at-Tahrīr wa at-Tanwīr, Vol. XV, (Beirut: Mu'asasah al-Tarikh al-'Arabi, 2000), h. 106.
} 
Arab. ${ }^{32}$ Artinya, kondisi sosial, geografis dan psikologi masyarakat Arab ketika itu merupakan salah-satu pertimbangan menarik yang diangkat Alquran ke permukaan.

Berdasarkan fenomena di atas, maka upaya interpretasi terhadap kitab suci ini yang hanya diorientasikan pada analisis kelas struktur gramatikalnya tidak akan cukup memadai mengejar kebenaran hakiki yang diusung teks. Pencapaian terhadap maknamakna itu tidak cukup berdasarkan analisa struktur kalimatnya saja, tetap perlu dikembangkan pada analisa kelas, struktur sosial dan budaya melatari kehadiran teks tersebut. ${ }^{33}$ Analisa terhadap kelas, struktur sosial dan budaya tersebut dalam kajian linguistik disebut ilmu pragmatik, yaitu disiplin kajian yang terikat konteks (contextdependent), ${ }^{34}$ baik konteks linguistik (linguistic meaning) yang bersifat diadik, maupun konteks non-linguistik (speaker meaning) yang bersifat triadik.

Kedua, Alquranadalah kitab suci yang menggunaakan media bahasa yang sarat makna (yahtamil al-wujūh li al-ma'nā). Kondisi multiple meaning tersebut disebabkan faktor internal (al-'awāmil al-dākhiliyyah) kebahasaan ayat Alquran yang memberikan berbagai kemungkinan "ruang kosong", dalam satu sisi, serta adanya faktor eksternal (al-'awāmil al-khārijiyyah) subyektifitas sang mufassir, pada sisi yang lain, sehingga muncul literatur tafsir yang kental dengan pewarnaan ideologis dan tendensius (talwiniyyah mugridah) ${ }^{35}$ semisal tafsir yang bernuansa falsafi, i'tiqadi, fiqhi, sufi dan adabi ijtima' ${ }^{36}{ }^{6}$ Karena itu, upaya interpretasi terhadap kitab suci ini tentu tidak akan pernah cukup untuk mendapatkan pemahaman yang objektif-totalistik jika hanya dikonsultasikan pada aspek strukturalnya saja. Sebab pembacaan secara struktural, hanya diorientasikan pada pemahaman posisi subyek, predikat dan objeknya saja, tanpa dinegosiasikan pada konteksnya. ${ }^{37}$

Kecuali itu, upaya interpertasi yang hanya mengandalkan pada anlisa semantik, baik pada level kajian makna leksikal maupun makna gramatikal, juga tidak akan cukup ruang menemukan maqāṣid al-shar̄̄ah yang dituju Alquran. Sebab kajian tersebut hanya terpusat pada kajian makna kata, klausa serta kalimat yang bebas

\footnotetext{
${ }^{32}$ M. Fārūq an-Nabhān, al-Madkhal Li at-Tasyrī' al-Islāmī, (Beirut: Dār al-Qalam, 1981), h. 83.

${ }^{33}$ Abd Muqsith Ghazali, Metodologi Studi al-Qur'ān, h. 119. Bandingkan dengan; 'Abd as-Ṣabūr Syāhīn, 'Arabiyyat al-Qur'ān, h. 67.

${ }^{34}$ Jenny Thomas, Meaning In Interaction; An Introduction To Pragmatics (London and New York: Routledge, 1995), h. 1-3. Lihat juga; Patrick Griffiths, An Introduction To English Semantics and Pragmatics (Edinburgh: Edinburgh Universtiy Press, 2006), h. 1-6. Bandingkan dengan; Bambang Kaswati Purwo, Pragmatik dan PengajaranBahasa; Menyibak Kurikulum 1984 (Yogyakarta: Kanisius, 1990), h. 16.

${ }^{35}$ Nasr Hamid Abu Zaid, al-Nas, al-Sultah, al-Haqiqah; al-Fikriyyah al-Diniyyah baina Iradat alMa'rifat wa Iradat al-Haimanah, (Beirut: al-Markaz ats-Tsaqafi, 1995), h. 120.

${ }^{36}$ Dalam konteks ini, literatur menarik yang membahas tentang corak dan ideologi penafsiran, bisa dilihat misalnya, Muhammad Husein al-Zahabi, al-Tafsir wa al-Mufassirun (t.tp.: tp., 1396). 'Abd alQadir Muhammad Salih, al-Tafsir wa al-Mufassirun fi al-'Asri al-Hadith (Beirut: Dar al-Ma'rifah, 1424). Ignaz Gold Ziher, Mazahib al-Tafsir al-Islami, (Beirut: Dar Iqra', 1403). Fahd 'Abdurrahman bin Sulaiman al-Rumi, Ittijahat al-Tafsir fi al-Qarn 'Ashr (Riyad: Mu'asasah Risalah, 1418). Lihat selengkapnya; Musa Ibrahim al-Ibrahim, Buhuth Manhajiyyah fi 'Ulum Alquran al-Karim (Amman: Dar 'Ammar, 1996), h. 91-120.

${ }^{37}$ Bambang Kaswati Purwo, Pragmatik dan PengajaranBahasa, h. 11-12.
} 
konteks (contect independent). Sementara, Alquran itu sendiri merupakan kitab suci yang diturunkan terikat konteks (contect dependet) mengingat ia diturunkan dalam rangka merespon realitas sosial komunitas Arab, sebagaimana kasus yang terjadi dalam Qs. al-A'lā (87): 14-15. ${ }^{38}$ Karena itu, pemahaman yang didasarkan pada kajian pragmatik merupakan pilihan tepat untuk menemukan "angan-angan sosial" Alquranyang sesungguhnya.

\section{Cara Kerja Pragmatika Alquran}

Konsep pragmatika Alqurandalam analisisnya mempunyai tahapan-tahapan atau cara kerja, yaitu analisis aspek sintaksis, aspek semantis, kemudian pada aspek pragmatis. ${ }^{39}$ Cara kerja yang demikian, dalam penelitian ini penulis formulasikan sebagai berikut;

Pertama, konteks linguistik, yaitu pembacaan terhadap ayat Alquranyang dikaji dengan menggunakan sudut pandang gramatikalnya yang meliputi sintaksis (annahwu), morfologi (as-șorfu) dan semantik (al-mufradāt). Hal ini dimaksudkan sebagai bahan kajian untuk mendapatkan pemahaman berdasarkan wujud formalnya.

Kedua, konteks non linguistik, yaitu pembacaan ayat Alqurandilanjutkan pada enam dimensi, berupa; tempat dan waktu (setting); pengguna bahasa (participants); topik pembicaraan (content); tujuan (purpose); nada (key); media (channel). ${ }^{40} \mathrm{Kajian}$ terhadap enam dimensi konteks tersebut dalam kajian 'uhüm Alqurandisebut sabab annuzūl, baik konteks makro (sabab an-nuzūl 'āmmah) maupun konteks mikro (sabab annuzūl khāsșah). Wilayah kajian ini dimaksudkan untuk menemukan pesan moral objektif yang berada dibalik teks mengingat tidak semua teks bisa dipahami berdasarkan wujud formalnya.

Ketiga, analisis terhadap objek kajian pragmatika al-Qur'ān. Menurut Nababan, objek kajian yang disepakati tokoh linguistik dalam studi pragmatik meliputi empat hal; (a) deiksis yang diorientasikan pada kata ganti.(b) implikatur yang dorientasikan pada makna dibalik teks. (c) praanggapan yang diorientasikan pada asumsi dasar suatu kalimat. (d) tindak tutur yang diorientasikan pada maksud tuturan.

\footnotetext{
${ }^{38}$ Kalimat "man tazakkā" dan "fa șallā" yang terdapat dalam Qs. al-A'lā (87): 14-15 jika diinterpretasikan berdasarkan pemahaman struktural dan semantik, maka ia berarti perintah menunaikan zakat fitrah (tazakkā) dan shalat ied (fa șallā) adalah tindakan pemahaman yang tidak objektif mengingat perintah kedua ritual tersebut baru diberlakukan sewaktu Rasulullah berhadapan dengan komunitas Madinah, sementara ayat tersebut diturunkan pada saat Rasulullah saw masih berdomisili di Mekkah. Karena itu, jika ayat tersebut dikonsultasikan dan negosiasikan pada konteksnya, maka menurut pemahaman Ibnu Abbas- menunjukkan, bahwa kalimat tazakkā berorientasi pada kritik budaya politeisme (syirik) komunitas Mekkah dan kalimat fa șallā berarti perintah ritual shalat. Lihat selangkapnya: Ibnu al-Jauzī, Zād al-Mas̄ì fī 'Ilmi at-Tafs̄ir, Vol. VIII, (Beirut; Dar al-Fikr, 1407), 230. Lihat juga; Musā'id Sulaimān at-Ṭayā̄, at-Tafs̄̄r al-Lugawī li Alquranal-Karīm (Mekkah: Dar Ibnu alJauzi, t.th.), h. 30 .

${ }^{39}$ Moh. Ainin, Fenomena Pragmatika dalam Alquran (Malang: Misykat, 2010), h. 14-18.

${ }^{40}$ Ronald Wardhaugh, An Introduction to Sociolinguistics (Hongkong: Blackwell Publishing, 2006), h. 242-248.
} 


\section{Kontribusi Kajian Pragmatik dalam Kajian Tafsir Alquran \\ Perlokusi sebagai Instrumen Penentu Maksud Penutur}

Suatu kalimat, wacana atau diskursus bisa dipahami dengan utuh dan totalitas apabila terdapat instrument yang dapat membongkar isi pesan yang terdapat dalam kalimat tersebut.Instrumen yang demikian dalam kajian ilmu pragmatik disebut perlokusi, yaitukajian yang membahas tentang efek atau reaksi yang timbul dari mitra tutur setelah adanya kalimat atau wacana dari penutur.

Posisi reaksi atau respon mitra tutur tentu merupakan hal yang sangat urgen dalam suatu komunikasi, sebab dengan perlokusi tersebut kita bisa dapat menentukan apakah mitra tutur menerima atau menolak dengan kalimat atau wacana yang disampaikan oleh penutur. Selain itu, kontribusi dan urgensi membaca suatu kalimat dengan menggunakan instrumen perlokusi juga dapat menentukan apakah kalimat tersebut dimaksudkan sebagai bentuk kalimat informasi, perintah, larangan, pujian dan hinaan apabila terdapat suatu reaksi atau respon dari mitra tutur.

Dengan demikian, pembacaan terhadap suatu kalimat atau wacana yang menggunakan teori perlokusi merupakan bentuk rekonstruksi terhadap ilmu balāghah klasik, terutama dalam teori ilmu al-ma'ani yang hanya mengklasifikasikan kalimat atau komunikasi menjadi dua bagian, yaitu kalamkhabari (kalima informasi) dan insha'i (kalimat non informasi). ${ }^{41}$ Pembagian komunikasi tersebut cenderung bersifat parsialistik sebab tidak ada ruang khusus yang membahas bagaimana efek, respon atau reaksi yang timbul dari mitra tutur setelah mendapat informasi (kalam khabari) atau perintah (kalam insha'i) dari penutur.

Indikasi tidak adanya ruang kosong kajian yang fokus membahas bagaimana respon mitra tutur sebagai penentu maksud penutur dalam ilmu balaghah klasik bisa dilihat dalam kasus QS. Ali 'Imran: 36 sebagai berikut:

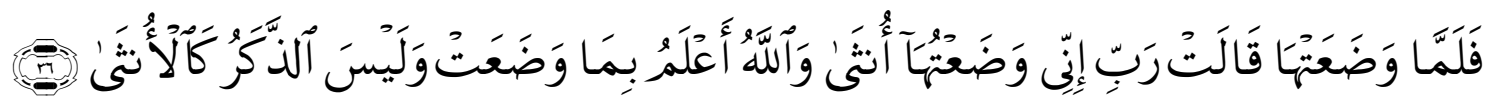

Artinya: "Maka tatkala isteri 'Imran melahirkan anaknya, diapun berkata: "Ya Tuhanku, Sesunguhnya Aku melahirkannya seorang anak perempuan; dan Allah swt.lebih mengetahui apa yang dilahirkannya itu; dan anak laki-laki tidaklah seperti anak perempuan”. (QS. Ali 'Imran [3] : 36) ${ }^{42}$

Ayat di atas merupakan reaksi Ibunda Hannah setelah melihat bayinya terlahir berjenis kelamin perempuan. Komentar yang terlontar pertama kali berupa kalimat inni wada'tuha untha (aku melahirkan seorang perempuan). Komentar tersebut muncul disebabkantidak adanya keselarasan antara idealita dengan realita. Artinya, idealita

\footnotetext{
${ }^{41}$ Ahmad al-Hashimi, Jawahir al-Balaghah fi al-Ma'ani wa al-Bayan wa al-Badi` (Beirut: Dar al-Fikr, 1414), h. 39-46.

${ }^{42}$ Departemen Agama RI, Alquran dan Terjemahnya, h. 54.
} 
bayi yang dirindukan Ibunda Hannah berjenis kelamin seorang lelaki, tetapi justru realita yang dilahirkannya berjenis kelamin perempuan. ${ }^{43}$

Menghadapi ayat di atas, terutama potongan kalimat inni wada'tuha untha, para ulama klasik, baik mufassir maupun ahli balaghah, fokus kajian mereka hanya dikonsentrasikan pada kalimat inni wada'tuha untha, sehingga menghasilkan kesimpulan bahwa potongan kalimat tersebut bukan berfungsi sebagai bentuk kalimat informatif-deklaratif (al-ikhbar wa al-i 'lam), tetapi jauh dari itu, berfungsi sebagai bentuk ungkapan rasa penyesalan (li al-i 'tidhar wa al-tahassur) atas kandasnya harapan Ibunda Hannah. ${ }^{44}$ Hal ini disebabkan, -bagi mereka-, terjadinya kontradiksi dengan kenyataan bahwa Allah swt. adalah Dzat yang Maha Mengetahui, sehingga sangat tidak mungkin dalam konteks demikian, Ibunda Hannah memberikan informasi kepada Allah swt tentang jenis kelamin yang dilahirkannya.

Berbeda dengan kajian di atas, potongan kalimat inni wada'tuha untha jika dinalisa dengan menggunakan ilmu pragmatik, terutama dalam teori tindak tutur, maka pemahaman terhadap ayat QS Ali 'Imran: 36 diklasifikasikan menjadi tiga kategori; Pertama, pembacaan lokusi. Potongan ayat"Ya Tuhanku, sesungguhnya aku melahirkannya seorang anak perempuan" dalam teori lokusi disebut kalimat informatif (khabariyyah), sebagaimana yang terdapat dalam makna gramatikalnya. Kedua, pembacaan illokusi, bahwa potongan kalimat tersebut merupakan bentuk asertif (assertives), yaitu bermakna mengeluh (complaining).Indikasinya dikarenakan dalam teori ilmu pragmatik terdapat pembahasan tentang tindak tutur perlokusi yang berorientasi pada the act of effecting someone. Bentuk perlokusi dalam konteks kisah ini, yaitu respon Allah swt. pada keluhan yang disampaikan penutur bahwa dirinya telah melahirkan bayi perempuan, berupa potongan ayat berikutnya, "dan Allah swt. lebih mengetahui apa yang dilahirkannya itu; dan anak laki-laki tidaklah seperti anak perempuan".

Oleh karena itu, kontribusi nyata kehadiran ilmu pragmatik dalam kajian ilmu Alquran dan tafsir, terutama kajian teori tindak tutur, dapat menentukan isi pesan yang disampaikan oleh penutur apakah berupa kalimat deklaratif, imperatif atau lainnya. Selain itu, kehadiran ilmu pragmatik dalam konteks kajian dan pengembangan ilmu Alquran dan Tafsir adalah menambah teori ilmu balaghah klasik, terutama dalam teori ilmu al-ma'ani yang hanya mengklasifikasikan bentuk komunikasi menjadi dua bagian, yaitu kalamkhabardan insha' menjadi tiga teori, yaitu kalam khabari, isnya'i dan perlokusi. Penambahan teori ini berarti menunjukkan adanya upaya bentuk rekonstruksi terhadap ilmu balaghah klasik. Upaya rekonstruksi, bahkan kritik terhadap ilmu balagah klasik jauh sebelumnya juga telah dilakukan oleh intelektual

\footnotetext{
${ }^{43} \mathrm{Abu}$ al-Qasim al-Zamakhshari, al-Kashshaf 'An Haqa'iq al-Tanzil, Vol. I (Beirut: Dar al-Kitab al'Arabi, 1407), 356. Bahrul Muhit, III, h. 116

${ }^{44}$ al-Razi, Mafatih al-Ghayb, Vol. VIII, h. 204.
} 
muslim, seperti Ahmad Shayib, ${ }^{45}$ guru besar di Universitas Cairo dan Husein Aziz, ${ }^{46}$ guru besar ilmu balaghah di UIN Sunan Ampel Surabaya.

\section{Implikatur sebagai Solusi Kebuntuan Pemahaman Tekstual-Gramatikal}

Dalam literatur-literatur klasik, posisi Sayyidah Maryam menjadi model dan tokoh yang debatable. Kehadiran sosok Sayyidah Maryam dalam Alquran mendapat respon kontroversial di kalangan para intelektual muslim, utamanya terkait persoalan kenabian, sehingga memunculkan dua kubu antra yang pro kenabian dan kontra kenabian. Salah-satu faktor signifikan yang memunculkan kontroversi tersebut disebabkan kedua belah pihak sama-sama menggunakan pendekatan tekstualgramatikal.

Pertama, pro-kenabian Maryam yang digagas oleh Ibnu Hazm. Kemudian, gagasan tersebut dilanjutkan oleh mufassir al-Qurtubi dengan tegas menyatakan status kenabian (al-nubuwwah) Maryam berdasarkan QS Ali 'Imran: 4247. Sebab dalam konetks ayat ini, menurut imam al-Qurtubi, bahwa Allah swt. memberikan wahyu dan mengutus malaikat Jibril kepada Maryam sebagaimana yang terjadi pada nabi-nabi lain. Kecuali itu, nama Maryam di dalam Alquran. Menurut al-Qurtubi disandingkan dengan kalimat siddiqah, sebagaimana sebutan yang sama juga diberikan kepada Nabi Idris as. dan Ibrahim as. ${ }^{48}$

Kedua, kontra kenabian Maryam. Kubu ini terdiri dari mayoritas para mufassir. Mereka menolak kenabian Maryam dengan beberapa alasan; (1) status kenabian dari kalangan perempuan bertentangan dengan QS al-Nahl: 43, bahwa, secara tekstual menjelaskan secara pasti status kenabian hanya diberikan kepada kaum laki-laki, bukan perempuan. ${ }^{49}$ (2) status kenabian Maryam, ibu Nabi Ishaq as dan ibu Nabi Musa as. tidak dijelaskan secara eksplisit dalam Alquran. (3) dialog antara Maryam dengan

\footnotetext{
${ }^{45}$ Klasifikasi ilmu al-bayan, ilmu al-ma'ani dan ilmu al-badi' dalam kajian ilmu Balagah menurut Ahmad al-Shayib, tidak bisa mengakomodir semua persoalan ilmu balagah. Karena itu, lanjutnya, topiktopik ilmu balagah seharusnya dikembalikan pada karakteristiknya yang paling penting, yaitu mutabaqah al-kalam li muqtada al-hal (kesesuaian ucapan dengan tuntutan keadaan atau konteks). Lihat selengkapnya; Ahmad al-Shayib, al-Uslub; Dirasat Balagiyyat Tahliliyyat li Usul al-Asalib al-Adabiyyat (Kairo: Maktabah al-Nahdat al-Misriyyah, 1990), h. 36-37.

${ }^{46}$ Klasifikasi ilmu al-bayan, ilmu al-ma'anidan ilmu al-badi', dalam pandanganya, masing-masing menyisakan problem kontradiksi teori. Kajian seputar ilmu al-bayan, utamanya teori tentang tashbih dinilai kontradiksi dengan Alquran sebab dalam kajian ilmu Balagah klasik bahwa tashbih yang tidak disebutkan sarana perbandingan dan titik persamaannya lebih kuat dan lebih efektif dari pada bentuk tashbih lainnya. Sementara Alquran sendiri banyak ditemukantashbih yang tidak menyebutkan sarana perbandingan dan titik persamaannya. Lihat selengkapnya; Husein Aziz, "Studi Kritis terhadap Ilmu Balagah Klasik”, Jurnal Islamica, Vol. 1, No. 2 Maret 2007, h. 174-180.

${ }^{47}$ Shamshu al-Din al-Qurtubi, al-Jami ‘ li Ahkam Alquran Wa al-Mubin lima Tadammanah min alSunnah Wa Ayi al-Furqan, Vol. IV (Riyaḍ: Dar 'Alam al-Kutb, 1423), h. 83.

${ }^{48}$ Ibid.,

${ }^{49}$ Muhammad bin Jarir al-Tabari, Jami“ al-Bayan fi Ta’wil Alquran, Vol. XVI (Beirut: Dar Mu'asasah, 1420), 293. Lihat juga; Muhammad Jamal al-Din al-Qasimi, Mahasin al-Ta'wil, Vol. VII (Beirut: Dar al-Fikr, 1421), 234. Lihat juga; Fakhr al-Din al-Razi, Mafatih al-Ghayb, Vol. VIII (Beirut: Dar Ihya' al-Turath, t.th.), 218. Lihat juga; al-Alusi, Ruh al-Ma'ani fi Tafsir Alquran al-'Azim, Vol. II, h. 149.
} 
malaikat Jibril tidak bisa dijadikan argumentasi logis kenabian Maryam sebab konsep kenabian itu secara terminologis merupakan wahyu dari Allah swt. yang diberikan kepada para nabi dengan cara-cara tertentu yang disampaikan melalui para malaikat. (4) penggunaan kalimat "wahyu" dalam Alquran tidak bisa digenaralisasi sebagai konsep kenabian. Karena itu, wajar jika dari dulu sampai sekarang tidak ada seorangpun yang menyatakan kenabian kepada lebah dan langit, ${ }^{50}$ sebab penggunaan kalimat wahyu dalam konteks kedua ayat tersebut hanya sebatas wahyu secara etimologis, yaitu pemberitahuan secara rahasia (al-i'lam fi al-khafa'). ${ }^{51}(5)$ kedatangan malaikat Jibril dan berdialog dengan Maryam dalam QS. Ali 'Imran: 42, hanya sebatas ilham semata. ${ }^{52}$ Hal ini disebabkan konteks pembicaraan ayat ini tidak ada indikasi yang mengarah pada persoalan konsep nubuwwah, sehingga wajar jika pada ayat berikutnya QS Ali 'Imran [03]: 43, Maryam diperintahkan untuk senantiasa bersujud dan ruku' sebagai ekspresi kesyukuran atas karunia superioritas yang diperolehnya. ${ }^{53}$

Kedua kubu di atas, hemat penulis sama-sama memperlihatkan penggunaan pendekatan gramatikal, sehingga problem kontroversi kenabian Maryam tidak pernah selesai.Dengan demikian, tentu diperlukan alat analisa dan instrument yang lebih canggih untuk mengakhiri konrtoversi tersebut, salah-satunya yaitu ilmu pragmatik dengan menggunakan teori implikatur. Teori ini digunakan dalam rangka untuk membongkar lapisan pesan dalam QS al-Anbiya': 91 yang menafikan penyebutan nama "Maryam".

Penafian nama "Maryam" tesebut dalam teori implikaturmenunjukkan bahwa Maryam bukan seorang nabi dari kalangan perempuan mengingat konteks pembicaraan dalam ayat sebelumnya, Qs al-Anbiya': 90 menceritakan tentang kisah para nabi dan putra-putranya. Kemudian pada ayat berikutnya, QS al-Anbiya': 91, Allah swt. menceritakan kondisi seseorang yang juga mempunyai posisi terhormat, namun karena ia bukan nabi, sehingga nama "Maryam" tidak disebutkan secara eksplisit. Dengan demikian, penafian dan pembuangan nama "Maryam" dalam teori implikatur mendekonstruksi pendapat imam al-Qurtubi yang mengklaim status kenabian Maryam sebab tesis tersebut hanya didasarkan pada QS. Ali 'Imran: 42, tanpa dikonsultasikan pada QS al-Anbiya': 91. Artinya, keberadaan QS. al-Anbiya': 91 jika dibaca dengan teori implikatur merupakan jawaban terhadap QS. Ali 'Imran: 42 bahwa Maryam bukanlah seorang nabi dari kalangan perempuan.

\section{Pragmatika sebagai Alat Pemahaman Berdasar Konteksnya}

\footnotetext{
${ }^{50}$ QS Fussilat: 11-12 dan QS al-Nahl: 68-69.

${ }^{51}$ Mahmud Baltaji, Madkhal ila al-Dirasat Alquraniyah, (Beirut: Maktabah al-Shabab, 1987), 87. Lihat juga; Abdul Basit Balbul, Dirasat fi 'Ulum Alquran, (Beirut: Dar al-Taba'ah al-Muhammadiyah, 1401), h. 17

${ }^{52}$ Al-Razi, Mafatih al-Ghayb, Vol. VIII, 218. Lihat juga: Muhammad Rashid bin 'Ali Rida, Tafsir alManar, Vol. III (Mesir: al-Hai' ah al-Misriyah, 1990), h. 246.

${ }^{53}$ Ahmad Mustafa al-Maraghi, Tafsir al-Maraghi, Vol. III (Mesir: Musatafa al-Babi al-Halibi, t.th.), h. $150-151$.
} 
Sebagaimana mafhum, bahwa jumlah total ayat-ayat Alquran terdiri dari 6.666 ayat. Dari sekian ribu jumlah ayat yang terdapat dalam Alquran, substansi kandungan isinya hanya mencakup 5 persoalan pokok, yaitu teologi (al-tauhid), hukum (al-hukm), etika (al-akhlaq), sejarah atau kisah (al-qissat) dan isyarat ilmiyyah (al-isharat al'ilmiyyah). Dengan demikian, fenomena ini tentu menunjukkan bahwa akan ada banyak bentuk pengulangan (repetitive) redaksi yang terdapat dalam Alquran.

Salah-satu indikasi bentuk repetitif dalam Alquran, misalnya, dapat ditemukan dalam kasus respon Sayyidah Maryam terhadap informasi penganugerahan seorang yang diinformasikan Malaikat Jibril. Respon tersebut disampaikan oleh Sayyidah Maryam dalam bentuk mempersoalkan strategi serta dengan cara bagaimana dirinya punya anak. Hanya saja, Maryam menggunakan bentuk kalimat yang "nyaris" sama. Hal ini bisa terlihat dalam dua ayat sebagai berikut:

Pertama, respon positif Maryam yang terdapat dalam QS Maryam: 20-21 yang diturunkan pada periode Mekkah.

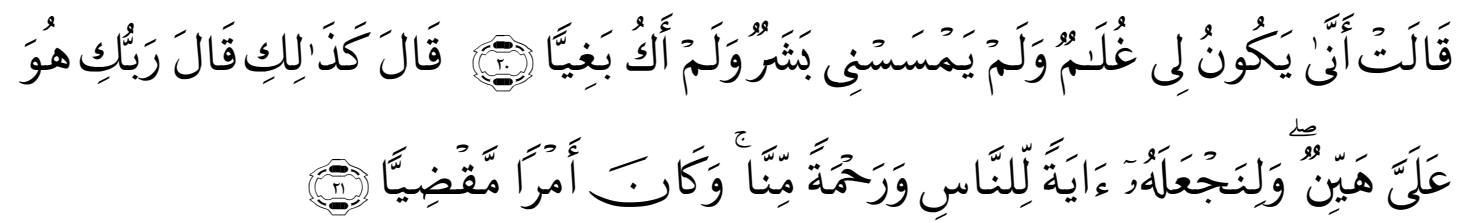

Artinya: (20). Maryam berkata: "Bagaimana akan ada bagiku seorang anak laki-laki, sedang tidak pernah seorang manusiapun menyentuhku dan aku bukan (pula) seorang pezina!" (21). Jibril berkata: "Demikianlah". Tuhanmu berfirman: "Hal itu adalah mudah bagiku; dan agar dapat Kami menjadikannya suatu tanda bagi manusia dan sebagai rahmat dari kami; dan hal itu adalah suatu perkara yang sudah diput uskan". (QS. Maryam [19] : 20-21)

Kedua, respon positif Maryam yang terdapat dalam QS Ali 'Imran: 47 yang diturunkan pada periode Madinah.

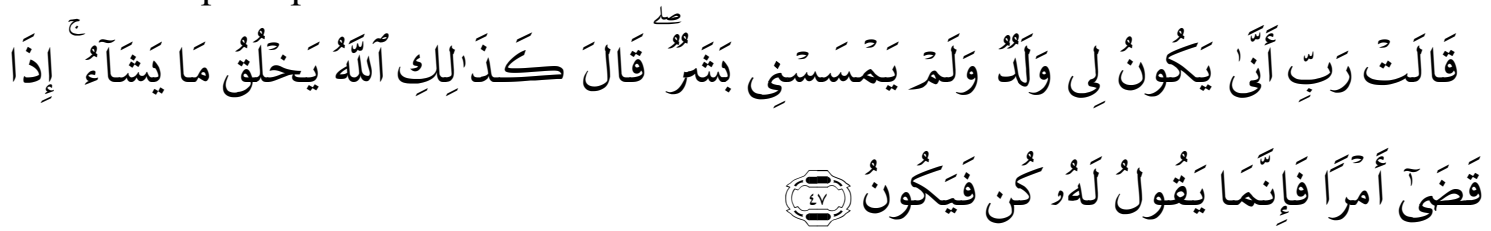

Artinya: Maryam berkata: "Ya Tuhanku, betapa mungkin aku mempunyai anak, Padahal aku belum pernah disentuh oleh seorang laki-lakipun." Allah berfirman (dengan perantaraan Jibril): "Demikianlah Allah menciptakan apa yang dikehendaki-Nya. apabila Allah berkehendak menetapkan sesuatu, Maka Allah hanya cukup berkata kepadanya: "Jadilah", lalu jadilah Dia. (QS. Ali Imran [3] : 47)

Jika dilihat dari bentuk redaksi dan susunan gramatikal yang terdapat dalam kedua kisah di atas, tampak sekali adanya perbedaan yang sangat mendasar, ${ }^{54}$ sebab

${ }^{54}$ Fungsi al-tikrar (bentuk repetisi) dalam Alquran, yaitu; Pertama, menunjukkan aspek retorikastilistika kalimat dalam bentuk nilai yang paling tinggi. Kedua, menegaskan bentuk mukjizat Alquran. Ketiga, memberikan atensi teramat besar terhadap kisah yang sedang disampaikan. Keempat, 
pengulangan kisah dalam Alquran jelas tidak sama persis dari berbagai aspeknya, baik kosa kata, kalimat, gaya bahasa dan deskripsi tokohnya, sehingga pembaca dan pendengar seolah-olah berhadapan dengan sajian kisah baru, sekalipun substansi tema kisahnya sama. ${ }^{55}$

Faktor yang melatarbelakangi perbedaan susunan redaksional dalam kisah Maryam ini dikarenakan adanya perbedaan konteks pembicaraan yang terdapat dalam kedua kisah tersebut. Kisah yang terdapat dalam QS Ali 'Imran: 47 merupakan kisah repetitif dari kisah yang terdapat dalam QS Maryam: 20. Perbedaan secara redaksional dan gramatikal tersebut, terlihat dalam beberapa hal:

Pertama, sinonimitas kata "anak".Kata tersebut diekspresikan dan dideskripsikan berbeda-beda, yaitu kata ghulam dan waladyang berarti seorang anak. Pertanyaan Maryam tentang proses pemberian anak yang disampaikan dalam QS Ali 'Imran: 47 menggunakan kata waladun, sebab pada ayat sebelumnya, Malaikat Jibril mengabarkan tentang proses pemberian anak tersebut dengan menyebut kata al-masih yang berorientasi pada seorang anak. Proses pemberian anak yang disebutkan dalam QS. Maryam: 20 dipertanyakan oleh Maryam dengan menggunakan kata ghulam sebab pada ayat sebelumnya, Malaikat Jibril mengabarkan proses pemberian tersebut dengan menggunakan kata ghulam. ${ }^{56}$ Dengan demikian, penggunaan kosa kata tersebut merupakan respon positif Maryam terhadap wacana yang disampaikan oleh Malaikat Jibril.

Kedua, relevansi teks dan konteks dalam penambahan kalimat wa lam aku baghiyyan yang terdapat dalam QS Maryam [19]. Penambahan kalimat "dan aku bukan pelacur" tersebut disesuaikan dengan konteks pembicaraan yang terdapat pada kisahkisah berikutnya dalam QS Maryam [19] itu sendiri, bahwa Maryam mendapatkan ocehan dari kaumnya ketika ia datang dengan membawa anak, namun anak yang masih dalam buaian tersebut justru bisa berbicara untuk membela ibunya. Berdasarkan fakta tersebut, maka penegasan bahwa, "aku bukan pelacur" dalam konteks ini menemukan bentuk relevansinya.Insiden yang demikian tidak dideskripsikan dalam QS Ali 'Imran [03], sehingga penyebutan "aku bukan pelacur" tidak perlu diungkapkan. ${ }^{57}$

Kecuali itu, penambahan kalimat tersebut juga berfungsi sebagai bentuk spesifikasi (li al-takhsis) dari kalimat wa lam yamsasni basharun. Spesifikasi tersebut tentu sangat diperlukan, sebab selain penggunaan kata al-massu yang berarti melakukan hubungan seksual secara halal maupun haram, juga penggunaan kata basharun dalam berbentuk nakirah (indefinitive) yang berarti semua orang laki-laki,

menyampaikan perbedaan maksud dan tujuan substansi persoalan. Lihat selengakpnya; Ibn 'Ashur, Tafsir al-Tahrir wa al-Tanwir, Vol. I, h. 68-69.

${ }^{55}$ Muhammad Sa'id Ramadan al-Buti, Min Rawa'i“u al-Bayan: Ta'ammulat 'Ilmiyyah wa Adabiyah fi Kitab Allah (Beirut: Mu’asasah al-Risalah, 1420), h. 199.

${ }^{56}$ al-Kirmani, al-Burhan fi Taujih Mutashabih Alquran, (Beirut: Dar I'tisam, 1977), 47. Lihat juga; al-Kirmani, Asrar al-Tikrar fi Alquran,h. 139.

${ }^{57}$ Ahmad Muhammad al-Sharqawi, al-Mar'at fi al-Qasas Alqurani, Vol. II (Kairo: Dar al-Salam, 1421), h. 683 . 
baik lelaki yang berstatus sebagai suaminya atau seorang laki-laki lain. ${ }^{58}$ Dengan demikian, tentu sangat tepat jika dalam konteks seperti ini Maryam mempertegas posisi dirinya dengan ungkapan kalimat wa lam aku bagiyyan.Ungkapan "aku bukan pelacur" tidak perlu diulang dan ditegaskan kembali dalam QS Ali 'Imran [03] mengingat surat tersebut dilihat dari sisi tartib al-nuzul-nya turun pada fase Madinah, sehingga wajar jika tidak lagi memerlukan penjelasan secara detail, bahwa Maryam bukan seorang pelacur..$^{59}$

Ketiga, diksi kalimat. Dalam konteks ini, Malaikat Jibril menjawab pertanyaan Maryam dengan menggunakan diksi kalimat yang berbeda-beda. Jawaban Malaikat Jibril yang terdapat dalam QS Maryam [19] disampaikan dengan cara mengutip langsung pernyataan Allah swt.,bahwa menciptakan atau menganugerahkan seorang anak untuk Maryam tanpa keterlibatan seorang ayah merupakan sesuatu yang mudah (hayyin) bagi-Nya. Jawaban Malaikat Jibril yang terdapat dalam QS Ali 'Imran [03] dijawab dengan menggunakan kalimat tidak langsung, bahwa Allah swt.menciptakan segala sesuatu sesuai dengan kehendaknya dengan menggunakan diksi katayakhluqu. Kata yakhluqusengaja dipilih agar mempunyai sisi perbedaan yang sangat kontras dengan kalimat yaf'alu yang digunakan dalam kisah penciptaan Nabi Yahya as, sebagaimana disebutkan dalam QS. Ali 'Imran: 40. ${ }^{60}$

Dengan demikian, perbedaan mendasar penggunaan redaksi yang "nyaris" sama dalam QS Maryam: 20-21 dan QS Ali 'Imran: 47 dalam teori pragmatik Levinson bisa dilihat dari dua hal;

Pertama, orientasi pada appropriateness in meaning (ketepatan isi). Orientasi ini, jika dilihat dari kategorisasi Makkiyyah-Madaniyyah perspektif Nasr Hamid, termasuk kategori realitas, yaitu perpindahan realitas dari tahap penyadaran dan peringatan (alindhar) pada fase Mekkah menuju realitas tahap pembentukan dan pemberian ajaran (al-risalah) pada fase Madinah. ${ }^{61}$ Karena itu, potongan ayat yang diekspresikan Malaikat Jibril dengan kalimat qala rabbuki huwa 'alayya hayyindalam QS. Maryam: 20 yang berbentuk penyadaran dan peringatan (al-indhar) pada fase Mekkah mengalami perubahan redaksi pada fase Madinah menjadi bentuk pemberian ajaran (al-risalah) yang diekspresikan dengan kalimatqala kadhaliki Allahu yakhluqu ma yasha' dalam QS Ali

\footnotetext{
${ }^{58}$ Tantawi, al-Tafsir al-Wasit, Vol. IX, h. 25.

${ }^{59}$ al-Andalusi, Tafsir al-Bahr al-Muhit, Vol. VII, 246. Lihat juga; Ibn 'Ashur, Tafsiral-Tahrir wa alTanwir, Vol. XVI, h. 22.

${ }^{60} \mathrm{Kata}$ yaf $\mathrm{f}$ alu mayoritas digunakan dalam konteks penciptaan sesuai dengan hukum kausalitas yang biasa dikenal manusia, seperti kelahiran Nabi Yahyā as dari proses hubungan intim antara seorang bapak dan ibu. Adapun kata yakhluqu hanya digunakan dalam konteks penciptaan yang tanpa menggunakan hukum kausalitas, seperti penciptaan Nabi 'Isa as. yang bertujuan untuk mempertegas bahwa Nabi 'Isa as. terlahir tanpa hukum kausalitas, karenanya ia terlahir tanpa kehadiran seorang ayah. Lihat selengkapnya; Rida, Tafsir al-Manar, Vol. III, 253.Selain itu, Selain itu, bisa juga kata yaf'alu berorientasi pada suatu pekerjaan yang mudah dikerjakan, kata yakhluqu berorientasi pada prosees penciptaan yang lebih sulit dari pada proses pekerjaan lainnya. Lihat selengkapnya; al-Samiri, Lamsat Bayaniyah, Vol. I, h. 661.

${ }^{61}$ Nasr Hamid Abu Zaid, Mafhum al-Nass; Dirasat fi 'Ulum Alquran (Beirut: Markaz al-Thaqafi al'Arabi, 1990), h. 78-79.
} 
'Imran: 47. Demikian pula, potongan kalimat wa kana amran maqdiyyan yang terdapat dalam QS. Maryam: 21 pada fase Mekkah yang berbentuk penyadaran dan peringatan (alindhar) juga mengalami perubahan redaksi menjadi bentuk pemberian ajaran (al-risalah) pada fase Madinah yang diekspresikan dengan kalimat idha qada amran fa innama yaqulu lahu kun fayakun di akhir QS Ali 'Imran: 47.

Kedua, orientasi appropriateness in form (ketepatan bentuk). Orientasi ini, dalam ketegorisasi Makkiyah-Madaniyyah Nasr Hamid termasuk kategorisasi teks, yaitu penggunaan gaya bahasa (al-uslub) berupa sajak berbentuk redaksi pendek serta mempertahankan fasilah ${ }^{62}$ yang berrima dan berirama pada fase Mekkah menuju redaksi panjang berbentuk prosa pada fase Madinah. Karena itu, penambahan redaksi wa lam aku baghiyyan dan penggunaan kalimat wa kana amran maqdiyyan di akhir ayat QS. Maryam: 20-21 pada fase Mekkah merupakan bentuk akomodasi gaya bahasa sajak yang singkat (ijaz) yang mempertahankan fasilah dari rima dan irama yang sama. Sementara pada fase Madinah, Alquran mengubah gaya penyampaiannyamenjadi uraian panjang (itnab), sehingga kisah jawaban Malaikat Jibril yang terdapat dalam QS. Ali 'Imran: 47 mengalami perubahan redaksi yang diekspresikan dengan kalimat kadhaliki Allahu yakhluqu ma yasha'idha qada amran fa innama yaqulu lahu kun fayakunmengingat Alquran tidak lagi berhadapan dengan komunitas Mekkah yang ahli sastra yang membangkang dakwah Rasulullah saw.

\section{Penutup}

Dari semua paparan di atas, penulis dapat menyimpulkan beberap hal sebagai berikut: Pertama, pragmatika Alquranadalah suatu disiplin ilmu yang mengkaji Alqurandari sudut pandang relasi antara konteks linguistik (linguistic meaning) yang bersifat diadik; dan konteks non-linguistik (speaker meaning)yang bersifat triadik.Kedua, asumsi dasar prgamtika Alquran adalah bahwa upaya interpretasi terhadap kitab suci yang hanya diorientasikan pada analisis kelas struktur gramatikalnya tidak akan cukup memadai mengejar kebenaran hakiki yang diusung teks. Karena itu, diperlukan pengembangan pada analisa kelas, struktur sosial dan budaya yang melatari kehadiran teks yang disebut ilmu pragmatik. Sedangkan langkahlangkahnya adalah analisa pada konteks linguistik, kemudian analisa pada konteks non linguistik dan diakhiri dengan kajian pada implikatur dan tindak tutur.Ketiga, kontribusi pragamtik dalam kajian tafsir Alquran menunjukkan bahwa, kehadiran teori perlokusi sebagai instrumen penentu maksud penutur, implikatur sebagai solusi kebuntuan pemahaman tekstual-gramatikal dan kehadiran pragmatika itu sendiri sebagai alat pemahaman berdasar konteksnya yang berorientasi pada appropriateness in meaningdan bisa jugaber

\footnotetext{
${ }^{62}$ Abu Zaid, Mafhum al-Nass; Dirasat fi 'Ulum Alquran,h. 90-91.
} 


\section{DAFTAR PUSTAKA}

Ainin, Moh. Pertanyaan dalam Al-Quran: Suatu Tinjauan Pragmatik, dalam alHadharah, Yogyakarta: UGM Press, 2001.

Alusi (al), 'Abdullah al-Husaini. Ruh al-Ma'ani fi Tafsir Alquran al-'Azim wa al-Sab'u al-Mathani, Vol. II. Beirut: Dar al-Kutub al-'Ilmiyah, 1415.

Andalusi (al), AbuHayyan. Tafsir al-Bahr al-Muhit, Vol. VII. Beirut: Dar al-Fikr, 1420.

'Ashur, Muhammad al-Tahir Ibn. Tafsir al-Tahrir wa al-Tanwir, Vol. III. Beirut: Mu'assasah al-Tarikh, 1420.

Balbul, Abdul Basit. Dirasat fi 'Ulum Alquran. Beirut: Dar al-Taba'ah alMuhammadiyah, 1401.

Baltaji, Mahmud. Madkhal ila al-Dirasat Alquraniyah. Beirut: Maktabah al-Shabab, 1987.

Baqi (al), Muhammad Fu'ad 'Abd. al-Mu'jam al-Mufahras li Alfaz Alquran. Kairo: Dar al-Kutb al-Misriyah, 1364

Buti (al), Muhammad Sa'id Ramdan. Min Rawa'i $u$ al-Bayan: Ta'ammulat 'Ilmiyyah wa Adabiyah fi Kitab Allah. Beirut: Mu'asasah al-Risalah, 1420.

Chaer, Abdul. Sosiolinguistik: Perkenalan Awal. Jakarta: Rineka Cipta, 2004.

Darwaish (al), Muhyiddin. I'rab Alquran wa Bayanuh, Vol. IV. Shiriai: Dar al-Irshad, t.th.

Dhahabi (al), Muhammad Husin. al-Tafsir wa al-Mufassirun. t.tp.: tp., 1396.

Eriyanto. Analisis Wacana: Pengantar Analisis Teks Media. Yogyakarta: LKiS, 2001.

Fathurrosyid. "Eksistensi Alquran: Kajian Ontologi, Epistemologi dan Aksiologi" dalam Studi Alquran. Surabaya: Kopertais IV Press, 2015.

Semiotika Kisah Alquran. Surabaya: Pustaka Radja, 2014.

Fauzi, Moch. Sony. Pragmatik dan Ilmu Ma'ani. Malang: UIN Maliki Press, 2011.

Gerald Gazdar, Pragmatic Implicature, Presupposition and Logical Form (New York: Academic Press, 1979

Ghazali, Abd Muqsith. Metodologi Studi al-Qur'ān. Jakarta: Gramedia Pustaka Agama, 2009.

Griffiths, Patrick. An Introduction To English Semantics and Pragmatics (Edinburgh: Edinburgh Universtiy Press, 2006.

Gunarwan, Asim. Pragmatik: Pandangan Mata Burung. Jakarta: Unika Atmajaya, 1993.

Gunarwan, Asim. "Dari Pragmatik ke Pengajaran Bahasa" dalam Makalah Seminar Bahasa dan Sastra Indonesia dan Daerah, IKIP Singaraja, 2004.

Hijazi, Mahmud Fahmi. 'Ilm al-Lughah al-'Arabiyah. Kairo: Dar Gharib, t.th.

Hashimi (al), Ahmad. Jawahir al-Balaghah fi al-Ma'ani wa al-Bayan wa al-Badi'. Beirut: Dar al-Fikr, 1414.

Ibrahim, Musa Ibrahim. Buhuth Manhajiyah fi 'Ulum Alquran al-Karim. Amman: Dar 'Ammar, 1996.

'Itr, Nur al-Din. 'Ulum Alquran al-Karim. Damaskus: Matba'ah al-Sabah, 1414.

Jauzi (al), Ibn. Zad al-Masir fi'Ilmi al-Tafsir, Vol. VIII. Beirut: Dar al-Fikr, 1407.

Khalifah, Akram. Jam'u Alquran: Dirasat Tahliliyah li Marwiyyatih. Beirut: Dar alKutb, 1427. 
Khuli (al), Amin. Manhaj Tajdid fi al-Nahw wa al-Balaghah wa Tafsir wa al-Adab.

Kairo: Dar al-Ma'rifah, 1961.

Kirmani (al). al-Burhan fi Taujih Mutashabih Alquran. Beirut: Dar I'tisam, 1977.

Kreidler, Charles W. Introducing English Semantic. London: Routledge, 1998.

Levinson, Stephent C. Pragmatic. Cambridge: Cambridge University Press, 1983.

Maqdisi (al), al-Husni. Fath al-Rahman li Talib Ayat Alquran. Jakarta: Diponegoro, t.th.

Maraghi, Ahmad Mustafa. Tafsir al-Maraghi, Vol. III. Mesir: Mustafa al-Babi alHalabi, t.th.

Mey, Jacob L. Pragmatics An Introduction. Hongkong: Blackwell Publishing, 2001.

Moleong, Lexy J. Metodologi Penelitian Kualitatif. Bandung: Remaja Rosdakarya,2009.

Mulyana.Kajian Wacana. Yogyakarta: Tiara Wacana, 2005.

Mustaqim, Abdul. Epistemologi Tafsir Kontemporer. Yogyakarta: LKiS, 2012.

Nababan, PWJ. Ilmu Pragmatik. Jakarta: Depdikbud, 1987.

Nabhan (al), M. Faruq. al-Madkhal li al-Tashri al-Islami. Beirut: Dar al-Qalam, 1981.

Nurkamto, Joko. Pragmatik. Surakarta: FKIP Universitas Sebelas Maret, 2002.

Purwo, Bambang Kaswati. Deiksis dalam Bahasa Indonesia. Jakarta: PN Balai Pustaka, 1984.

--------, Bambang Kaswati. Pragmatik dan PengajaranBahasa: Menyibak Kurikulum 1984. Yogyakarta: Kanisius, 1990.

Qasimi (al), Muhammad Jamal al-Din. Maḥasin al-Ta'wil, Vol. IV. Beirut: Dar Ihya' al-Turath, 1376.

Qurtubi (al), Abu Bakar Ibn Farah. al-Jami ‘ li Ahkam Alquran wa al-Mubin lima Tadammanah min al-Sunnah wa Ayi al-Furqan, Vol. IV. Riyad: Dar 'Alam alKutub.

Razi (al), Fakhr al-Din. Mafatih al-Ghayb, Vol. VIII. Beirut: Dar al-Kutb al-'Ilmiyyah, 2000

Rida, Muhammad Rashid Ibn 'Ali. Tafsir al-Manar, Vol. III. Mesir: al-Hai'ah alMisriyah, 1990.

Rumi (al),Fahd 'Abdurrahman bin Sulaiman. Manhaj al-Madrasah al-'Aqliyah alHadithah fi al-Tafsir. Riyad: al-Buhuth al-'Ilmiiyah wa al-Ifta', 1403.

--------,Fahd 'Abdurrahman bin Sulaiman. Ittijahat al-Tafsir fi al-Qarn al-'Ashr. Riyad: Mu'asasah Risalah, 1418.

Rustono. Pokok-pokok Pragmatik. Semarang: IKIP Semarang Press, 1999.

Salih, 'Abd al-Qadir Muhammad. al-Tafsir wa al-Mufassirun fi al-'Asri al-Hadith. Beirut: Dar al-Ma'rifah, 1424.

Sabag (al), Lutfi. Lamhat fi 'Ulum Alquran wa Ittijahat al-Tafsir. Beirut: al-Maktab alIslami, 1410.

Samiri (al), Fadil Salih. Lamsat Bayaniyyah li Surat Alquran, Vol. I. Beirut: Dar alFikr, t.th.

Shahin, 'Abd al-Sabur. 'Arabiyyat Alquran. t.tp.: Maktabah al-Shahab, t.th.

Sharqawi (al), Ahmad Muhammad. al-Mar'at fi al-Qasas Alqurani, Vol. I. Kairo: Dar al-Salam, 1421.

Sodiqin, Ali. Antropologi Al Qur'an. Yogyakarta: Arruz Media Group, 2008.

Suyuti (al), Jalal al-Din. al-Itqan fi 'Ulum Alquran, Vol. I. Beirut: Dar al-Fikr, 1414. 
Tabari (al), Muhammad Ibn Jarir. Jami' al-Bayan 'an Ta’wil Ayi Alquran, Vol. V. Beirut: Mu'assasah al-Risalah, 1420.

Tayyar (al), Musa'id Sulaiman. al-Tafsir al-Lughawi li Alquran al-Karim. Mekkah: Dar Ibn al-Jauzi, t.th.

Tarigan, Henry Guntur. Pengajaran Pragmatik. Bandung: Angkasa, 1990.

Thomas, Jenny. Meaning in Interaction: an Introduction to Pragmatics. New York: Longman, 1995.

Wardhaugh, Ronald. An Introduction to Sociolinguistics (Hongkong: Blackwell Publishing, 2006

Yule, George. Pragmatics. Oxford: Oxford Universty Press, 2006.

Zaid, Nasr Hamid Abu. Mafhum al-Nass; Dirasat fi 'Ulum Alquran. Beirut: Markaz alThaqafi al-'Arabi, 1990.

Zaid, Nasr Hamid Abu. al-Nas, al-Sultah, al-Haqiqah; al-Fikriyyah al-Diniyyah baina Iradat al-Ma'rifat wa Iradat al-Haimanah (Beirut: al-Markaz ats-Tsaqafi, 1995.

Zamakhshari (al), Mahmud Ibn 'Umar. al-Kashshaf 'an Haqa'iq Ghawamid al-Tanzil wa 'Uyun al-Aqawil fi Wujuh al-Ta'wil, Vol. I. Beirut: Dar al-Kitab, 1407.

Zarkashi(al), Badr al-Din. al-Burhan fi 'Ulum Alquran, Vol. II. Beirut: Dar Ihya' 'Arabi, 1957

Ziher, Ignaz Gold. Madhahib al-Tafsir al-Islami. Beirut: Dar Iqra', 1403. 